\title{
New ideas about the neotectonics and geomorphology of the Black Sea west margin
}

\author{
Svetla STANKOVA ${ }^{1} \odot$, Tzanko TZANKOV² $\odot$, Milena STOYANOVA ${ }^{1} \odot$
}

${ }^{1}$ Konstantin Preslavsky University of Shumen, Department of Geography, Regional Development and Tourism, Shumen, Bulgaria ${ }^{2}$ South-West University, Department of Geography, Ecology and Environmet Protection Blagoevgrad, Bulgaria

ORCID: S.S. XXX-XXXX-XXXX-XXX; T.T. XXXX-XXXX-XXXX-XXXX; M.S. 0000-0002-8459-3071

\begin{abstract}
The article introduces the results of the author's investigations about the origin, Quaternary morphotectonic evolution and the modern morphostructure of the Bulgarian Continental Microplate from the Eastern part of the Balkan Peninsula.

The research was realized on a base of the contemporary Plate tectonics study principia by means of the morphostructural analysis apply (Tzankov, 2013). It was provided the principal relief building role of the regional mosaic pattern and the listric faulting in the Eastern part of the Balkan Peninsula.

The Quaternary Earth superficial relief building processes were and are predominantly provoked and controlled by the Upper Mantle - Asthenosphere energy. Its Earth superficial effects are expressed by the relationships between the seismic effects and the regional faulting.

The East Balkan Peninsula Area was a part from the Tethys Ocean until 72000000 years. The pre Maestrichtian Geologic-Tectonic Pattern of cockle of the East Balkan Peninsula Area wasn't built on the Europe Continental Massif. The modern East Balkan Peninsula Relief is forming during the Late Quaternary Time.

The East Balkan Peninsula Margin coincides with the border between the Bulgarian and Moesian Continental Microplates from the west and the Black Sea Oceanic Microplate to the east. This border presents the Neo Europe West Passive Continental Margin in the area of the last Tethys Oceanic Fragment - it Black Sea Oceanic Gulf.
\end{abstract}

Keywords: Passive continental margin, Archipelago, Morphotectonic evolution, Seismic activity, continental fragment.

\section{öz}

Makale, yazarların Balkan Yarımadası́nın doğu kısmındaki Bulgar kıta mikroplakalarının kökenleri, dördüncül evrimleri ve çağdaş yapılarını araştırmasının sonuçlarını sunmaktadır.

Çalışma morphostructural analizi uygulanması için modern plaetektonik ilkeler temelinde yapıldı (Tzankov, 2013). Bölgesel mozaik yapının belirleyici rolü ve yaprak kırılması dikkate alınmıştır (bildirilmiş̧ir).

Dünya yüzeysel etkileri, sismik etkiler ile bölgesel faylanma arasındaki ilişkilerle ifade edilir.

Yüzey kazısının prosesleri önceden belirlenmiş ve üst manto astenosferik enerjisi tarafından kontrol ediliyor.

Bugünkü Balkan Yarımadası́nın doğu kısmının toprakları, 72 milyon yı önce Tetian Paleoceanının bir parçasıydı. Balkan Yarımadası́nın bugünkü doğu kısmının jeolojik-tektonik yapısı, Avrupa kıtasal katliamından önce mastriksten oluşmamıştır. Yarımadanın bu bölümünün modern kabartması, Geç Kuvaterner döneminde ortaya çıkmıştır.

Bu sınır, son Tethys Oceanic Parçası - Karadeniz Okyanusu Körfezi bölgesinde, Neo Avrupa Batı Pasif Kıta Marjını sunmaktadır.

Balkan Yarımadası Marjı, batıdan gelen Bulgar ve Moesian Continental Mikroplakaları, Karadeniz Okyanus Mikroplakası'ndan sınırla çakışıyor.

Anahtar Kelimeler: Pasif kıta kenarı, Takımadalar, Morfotektonik evrim, Sismik aktivite, Kıta parçası. 


\section{INTRODUCTION}

The article presents some new results of the author's investigations (Tzankov, 2009; Tzankov \& Stankova, 2011, 2012, 2014, 2015, 2016; Tzankov et al., 2017, 2018) about the origin, Quaternary morphotectonic evolution and the modern morphostructure of the Balkan Peninsula East Margin. The research was realized on a base of the contemporary Plate tectonic study principia by means of the morphostructural analysis apply (Tzankov, 2013).

\section{GENERAL MORPHOTECTONIC POSITION}

The East Balkan Peninsula Area was a part from the Tethys Ocean North West End until 72000000 years. The pre Maestrichtian Geologic-Tectonic Pattern of cockle of the East Balkan Peninsula Area wasn't built on the Europe Continental Massif. The modern East Balkan Peninsula Relief (Fig. 1) is forming during the Late Quaternary Time.

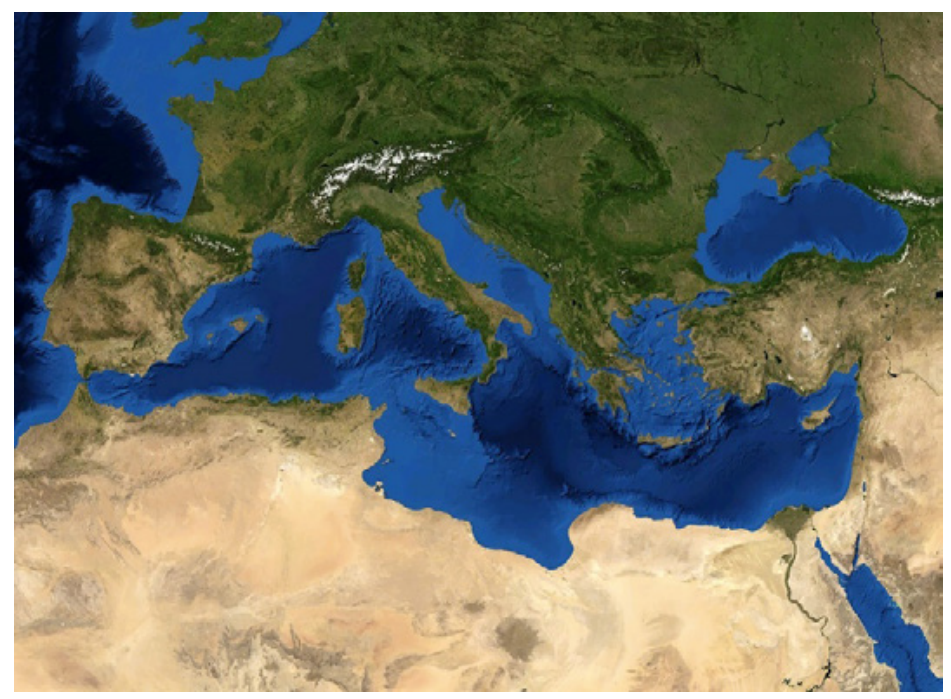

Figure 1: Black Sea - geographical position

Intra Mediterranean archipelago

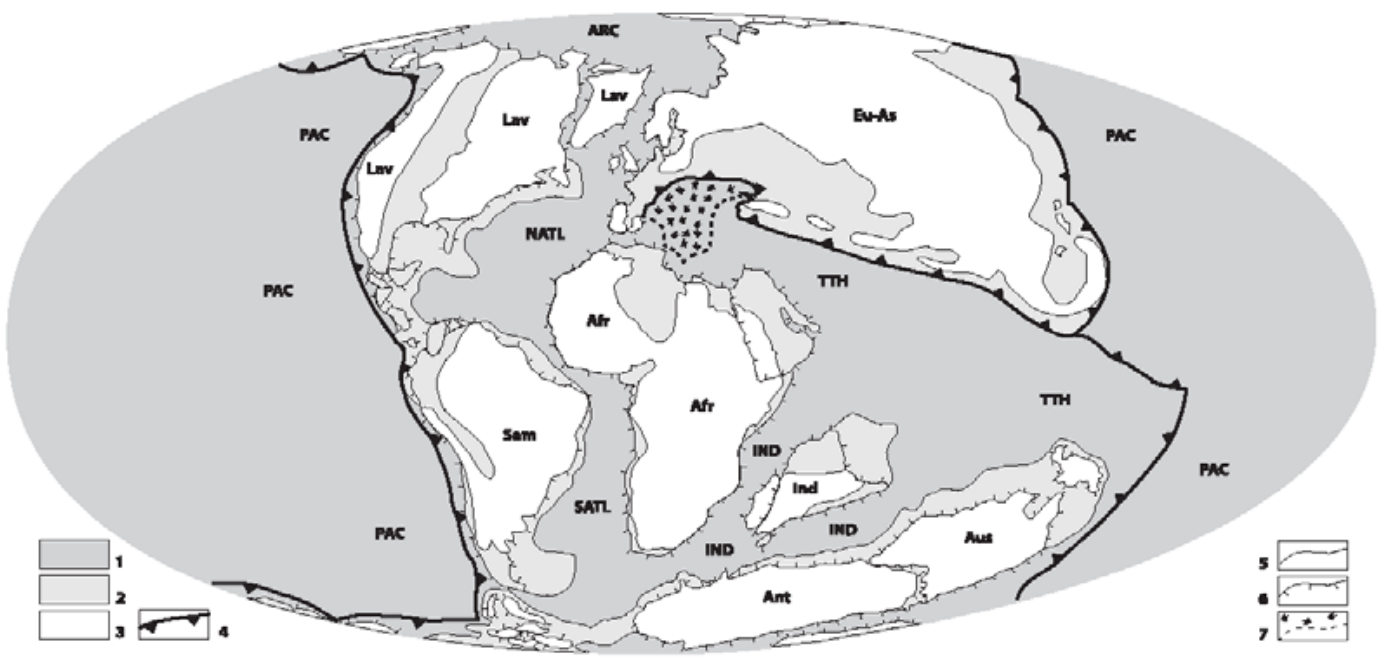

Figure 2: Provisional sketch of the Mediterranean Area during the Late Cretaceous (Coniacian-Santonian) West End Tethys Ocean Closing 
1 - ocean, 2 - epicontinental basin, 3- continent, 4- continental margin, 5- subduction, 6 - collision, 7- Intra Mediterranean Archipelago Zone. Oceans: PAC- Pacific, NATL- North Atlantic, SATL- South Atlantic, IND- Indian, ARC- Arctic, TTH - Tethys. Most continental massifs: Lav - North America (Lawrencia) (Proto Laurasia), Eu-As - Euro-Asia (Proto Laurasia), Sam - South America

(Proto Gondwana), Afr - Africa (Gondwana), Ind - India (Proto Gondwana), Ant - Antarctica (Proto Gondwana), Aus - Australia (Proto Gondwana).

The East Balkan Peninsula Margin coincides with the border between the Bulgarian and Moesian Continental Microplates from the west and the Black Sea Oceanic Microplate to the eats (Fig. 5). This border present the Neo Europe West Passive Continental Margin in the area of the last Tethys Oceanic Fragment - it Black Sea Oceanic Gulf (Fig. 2).

The Intra Mediterranean Archipelago (Fig. 2) was composed by numerous islands - fragments (domains) from the destructed Gondwana North Margin during the Late Cretaceous Tethys Subduction (Fig. 3).

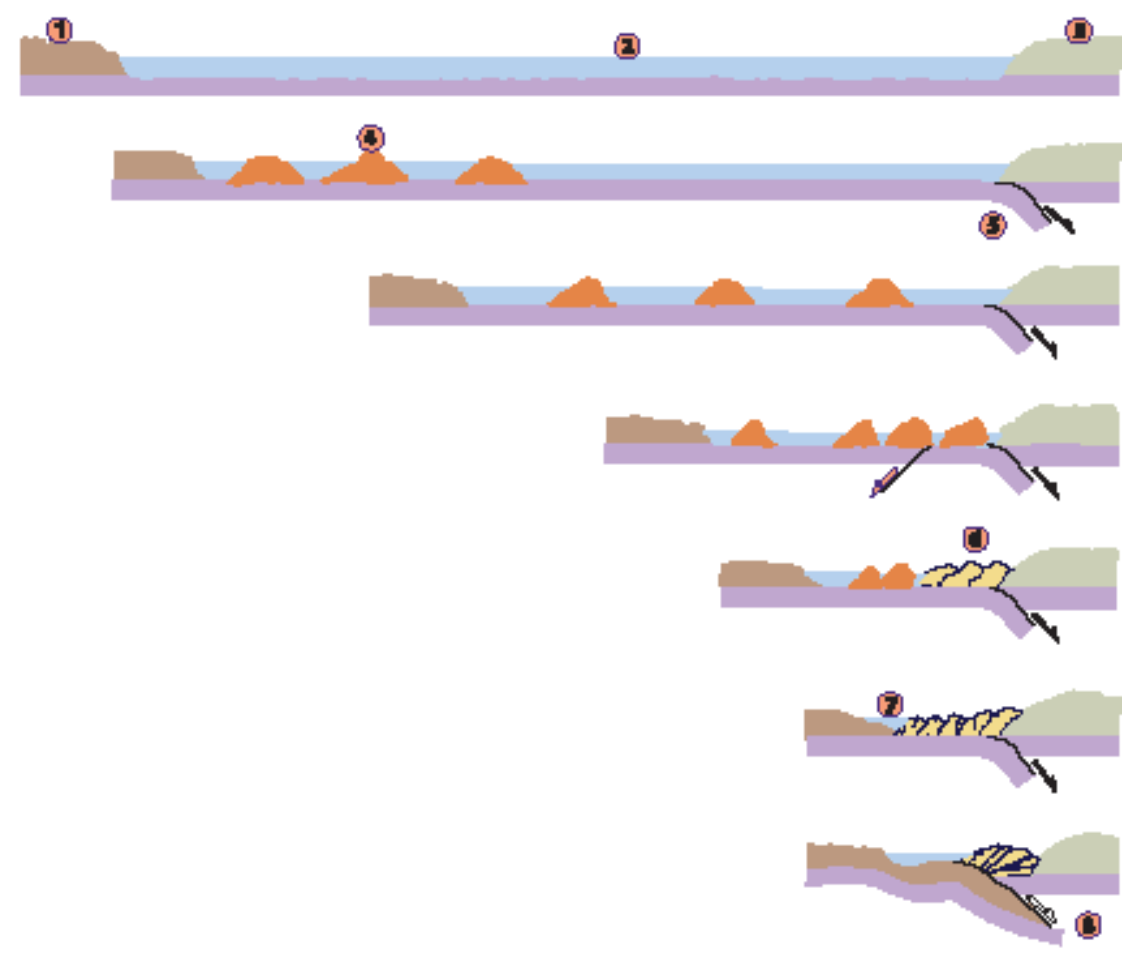

Figure 3: Moments from the Tethys Ocean Closing (after Tzankov)

1- Gondwana continental massif, 2- Tethys Ocean, 3- Paleo Europe Continental Massif, 4 - Gondwana Continental Crust Fragments in the Tethys Ocean - Intra Mediterranean Archipelago, 5 - Tethys Ocean Phanerozoic Subduction down the Paleo Europe Continental Massif, 6- Neo Europe Continental Massif Building 7- Mediterranean See Building (after the Tethys Ocean Closing), 8- intra continental collision between of the Gondwana and the Neo Europe Continental Massif 


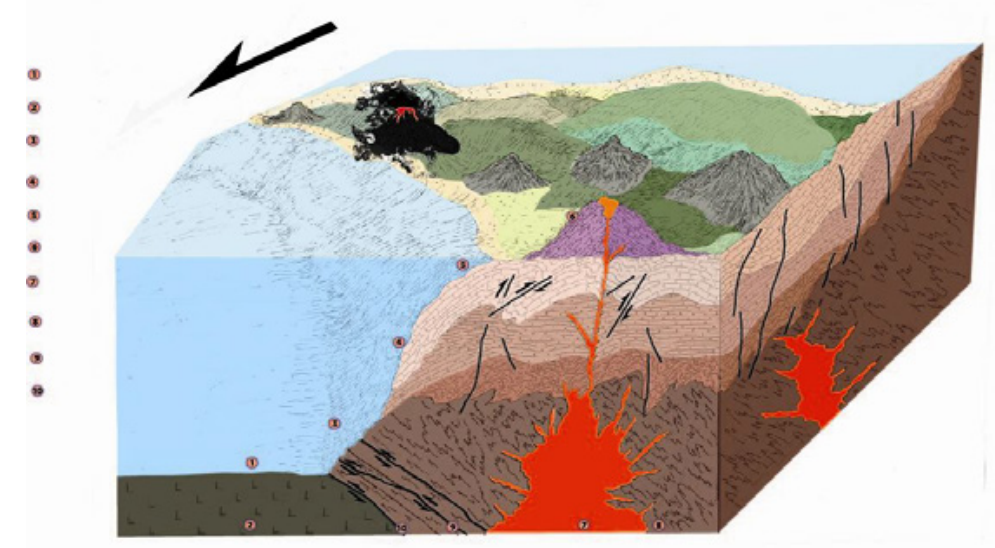

Figure 4: Block diagram model of the Gondwana Continental Fragments (belong to the Mediterranean archipelago) Internal Pattern in the Tethys Ocean

1 - oceanic bottom, 2 - oceanic crust, 3 - continental foot, 4 - continental slope, 5 - shelf , 6 - volcano

The archipelago continental domains have heating on the Paleo Europe South Rand in the time of Tethys Closing End (Fig. 3). They have welded (suturated) and builder the New Europe Continental Massif (Fig. 5). The last one is contemporary represented by the Moesian and Bulgarian Continental Microplates (in the Balkan Peninsula East Margin). Those two New Europe Domains contact with Black Sea Oceanic Microplate to the east.

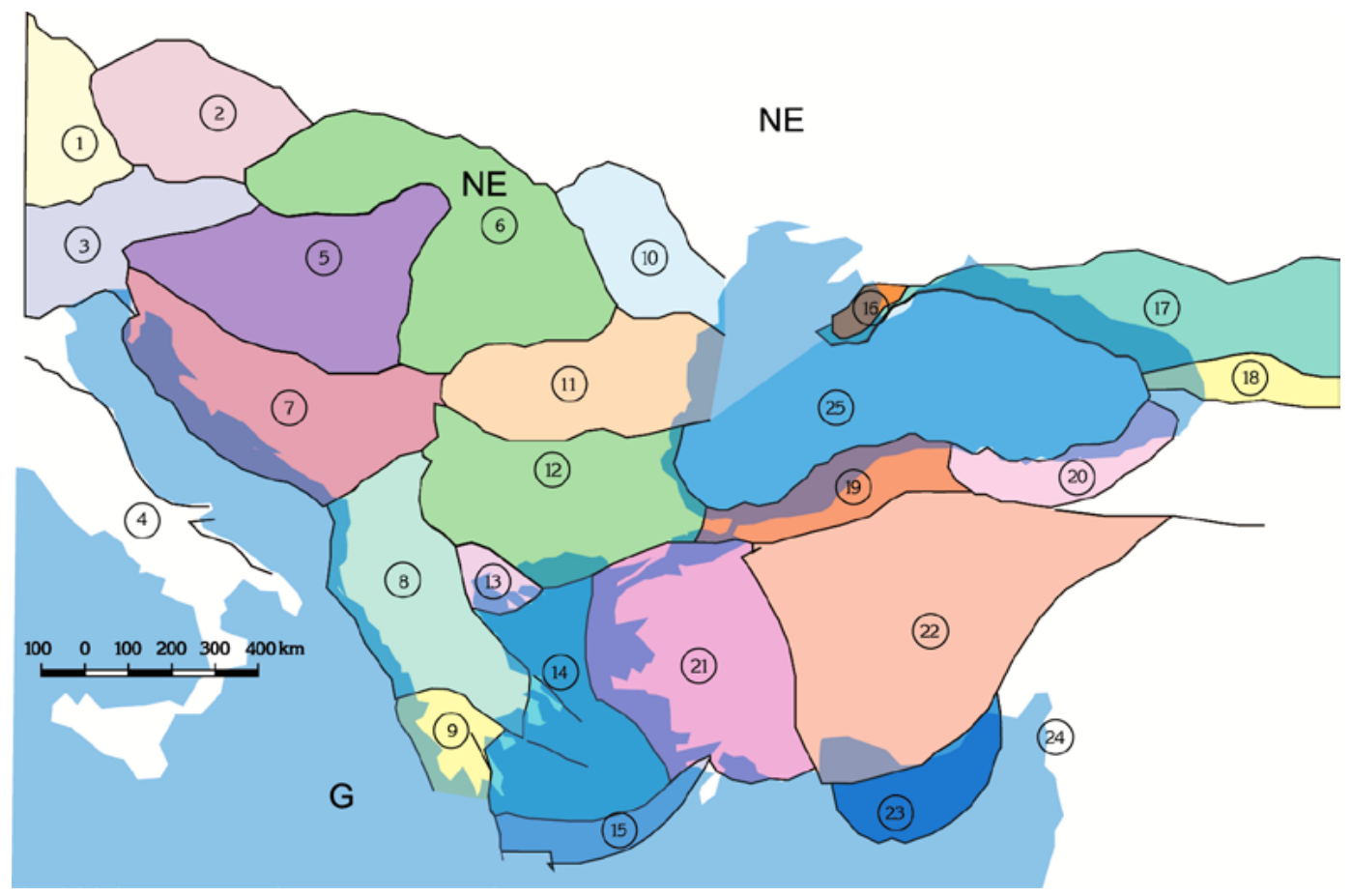

Figure 5: Sematic model of the Neo Europe Mosaic Tectonic Pattern

1-23 - continental microplates: 1- Bavarian, 2- Bohemian, 3- Alpean, 4-Apeninian, 5- Moravian, 6- Carpathian, 7- Dinarian, 8- Pindian, 9- Heladian, 10- Skitian, 11-Moesian, 12- Bulgarian, 13- Halkidikian, 14- Aegean, 15- Cretean, 16- Creamean, 17- Caucasean, 18- Georgian, 19- West Pontidan, 20- East Pontidan, 21- West Anatolian, 22- East Anatolian, 23- Cyprian, 23- Arabian Plate; 25- Black Sea (Pontian) Oceanic Microplate 


\section{Main characteristics of the Black Sea basin}

The Black Sea Basin is distinguished from the enclosed continental microplates and epicontinental basins through:

1. Deep, large, relatively flat sea bottom (Fig. 6), formed in the rocks of the lower basalt layer from the Earth Crust.

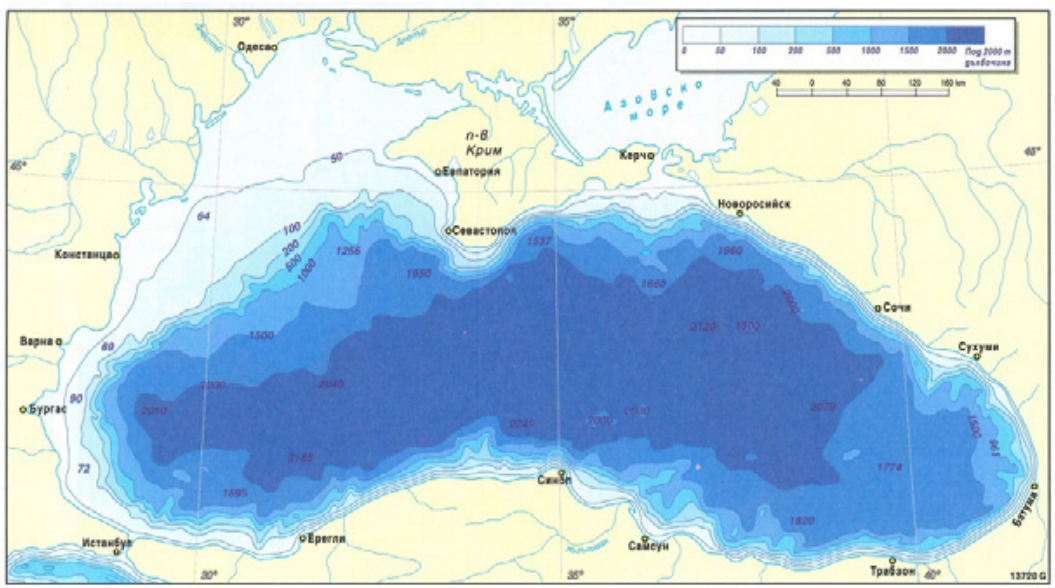

Figure 6: General view of the Black Sea Bottom

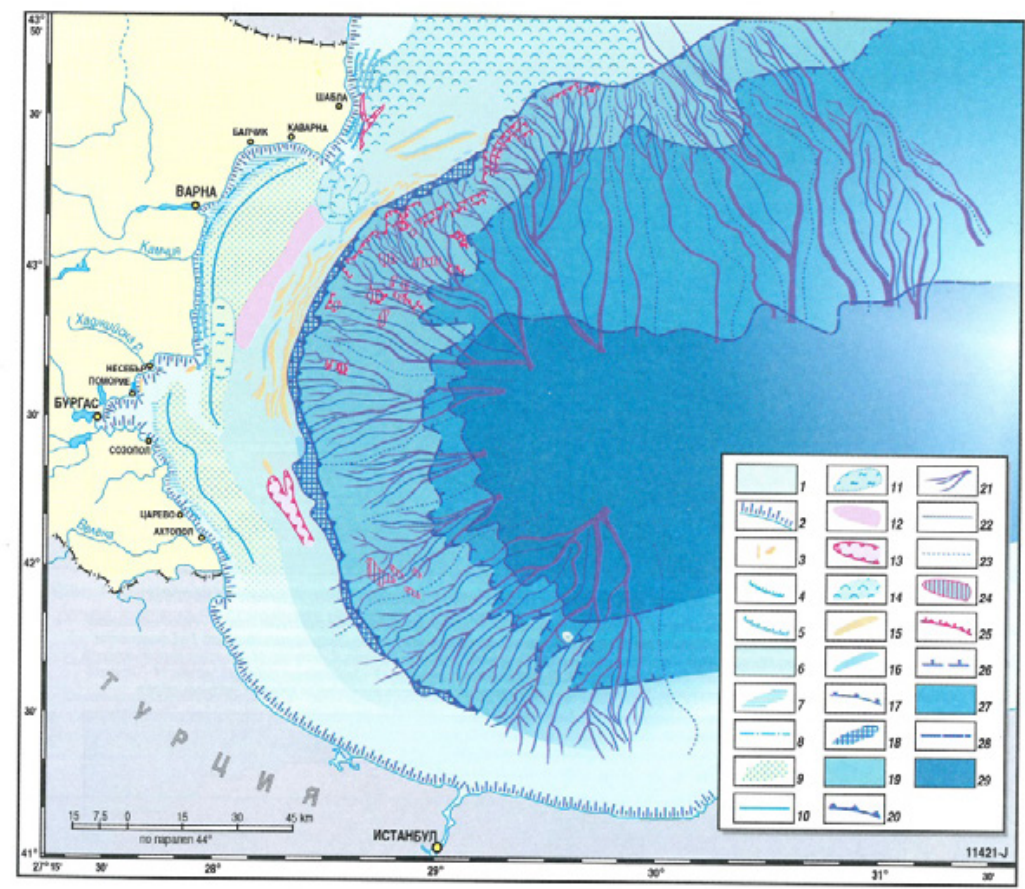

Figure 7: Sketch map of the Black Sea Western Continental Margin

2. The sea shelf's and sea slopes of the Black Sea Basin represent typical passive continental margin (Fig. 7) of the enclosed continental microplates (Fig. 8).

3. In the Black Sea Basin were established very typical only for the oceans natural events „Tsunami”.

4. The water of the Black Sea Basin is included the characteristically only for the ocean basins suppurated sulfur hydrogen ( $\left.\mathrm{H}_{2} \mathrm{~S}\right)$ layer. 
5. The Earth Crust on the Black Sea Basin bottom is relatively thin $(20-30 \mathrm{~km})$ in comparison with the Earth Crust of the marginal continental massifs $(30-50 \mathrm{~km})$.

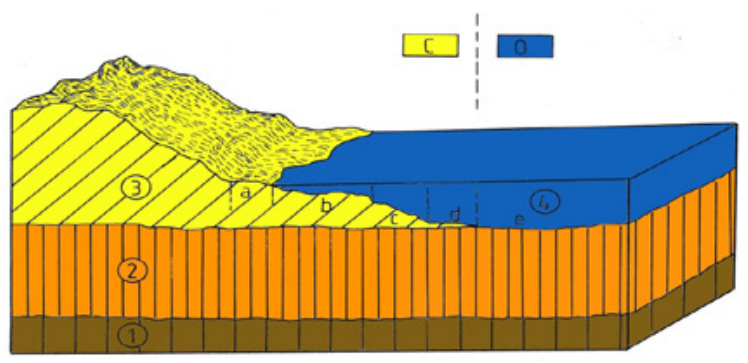

Figure 8: Schematic block diagram of the Western Black Sea Passive Continental Margin

1 - Upper Mantel; 2-3- Earth Crust: 2- „basalt” Layer, 3- „granite” and „sediment” layers: a- shelf, b- submarine shelf, c- continental slope, d- continental foot, e - oceanic bottom

\section{Former concepts}

The along the last sanctuary elapsed discussions about the origin and morphotectonic evolution of the region of the Black Sea Basin have formed the following hypothesis:

1. The Black Sea Basin is result of continental rifting;

2. The Black Sea Basin is effect of one uncompensated epicontinental depression;

3. The Black Sea Basin represent a deep water uncompensated kettle.

Everyone former investigators holed up the attitude, that the Black Sea Basin is one epicontinental marine basin.

The stand-point about the Black Sea Basin continental rifting origin is groundless for lack of rifting morphostructures and rifting relief on the see bottom. The basin concerned is not „epicontinental”, because it bottom is completely builder by the basalt (and not by granite) Lear of the Earth Crust. The Black Sea Basin isn't kettle bottom towards the marginal continental massifs. The ,uncompensated” character of the basin is one allegation.

\section{Proposed mobility interpretation}

The Black Sea Basin was a large Gulf in the north-eastern coast of the Phanerozoic Tethys Ocean (Fig.9). Its south-eastern margin was marked by the difference in the time spatial disposed Anatolian (Little Asia) Peninsula. The last one was moved to the north-west under the pressure of the Arabian and Persian continental plates during the last $20 \mathrm{M}$. y. The frontal west-northwestern margin of the Anatolian Peninsula was arrived the Balkan Peninsula (in the area of Bosporus) in the time of the completely Tethys Ocean Closing (in the Eastern Mediterranean) and the Gondwana /Europe Intercontinental Collision Beginning. The little fragment from the oceanic crust in the area of the contemporary Black Sea Basin was remained as a Black Sea Oceanic microplate. 


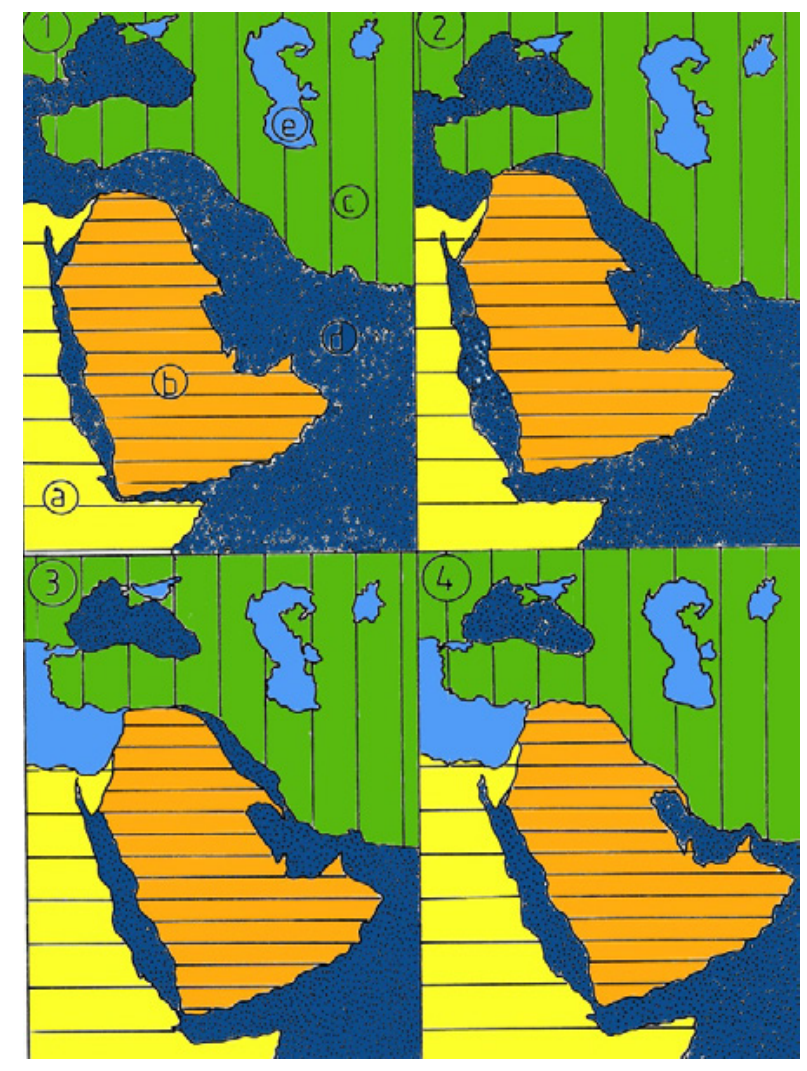

Figure 9: Consecutive moments from the Black Sea differentiation

a - Gondwana continental Massif, b- Arabian Continental plate, c- Euro-Asia Continental Massif, d- Tethys Ocean

1- time Arabian Plate Separation from of the Gondwana Continental Massif; 2- touching time between Arabian Continental Plate and Little Asia Continental Fragments*; 3- Mediterranean Sea Basin Building; 4 - contemporary situation

*Remark: the question of the Little Asia Continental Fragments Primary Tectonic Belonging to the Gondwana Continental Massif or to the Euro-Asia Continental Massif is debatable

\section{Principal characteristics of the West Black Sea passive continental margin}

The West Black Sea Passive Continental Margin has a very clear west fault border (Fig. 10). It came in to being during the Paleocene time, immediately after the suturing between the different continental fragments (terrains) in this part of Neo Europe Continental Massif.

The morphounits in the subaeral part of the margin are lower everywhere to the east. This is an important difference with the morphostructural pattern of the most west part from the Moesian and Bulgarian continental microplates.

The East part of the Stara Planina mountain range loses its unity and "disfingers" its crest in the area of the West Black Sea passive continental margin.

The firth and lagoon abundance on the Bulgarian Black Sea Coast show the morphotectonic "calm" and passive character of the West Black Sea continental margin.

The firsts of the Primorska and Sakar-Strandzha Morphostructural Zones are formed in the mountain relief of the coast. This event is not observed in the other parts of the Black Sea Coast .

The seismic activity in the area of the West Black Sea passive continental margin is sharply reduced in comparison with the most west part from the Moesian and Bulgarian Continental Microplates The not numerous earthquake centrums are group together the some Quaternary active faults or fault zones. 
The separate morphotectonic parts of the West Black Sea Passive Continental Margin have the some mosaic block pattern of the respective morphostructural unit.

The West Black Sea passive continental margin shows spatial satisfactory dimensional character along the whole it length. It origin, orographic and morphotectonic characteristic is essentially different from the north and south Black Sea coasts.

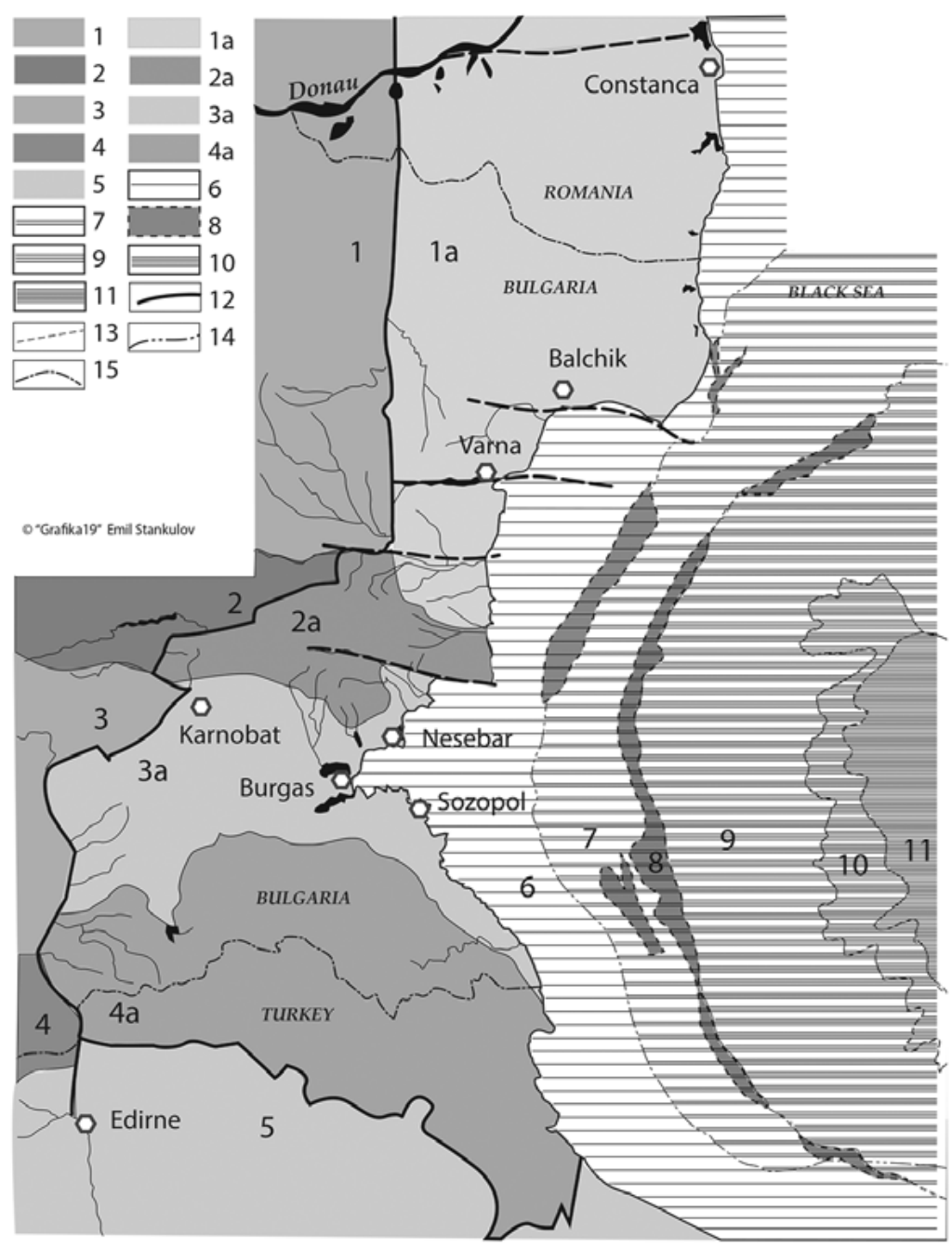

Figure 10: Morphostructural sketch of the West Black Sea Passive Continental Margin

1-5 - subaerial margin area: 1-1a - South Moesian Morphostructural Zone: 1- continental part, 1a- margin part: 2-2a -Hemus Morphostructural Zone: 1- continental part, 1a- margin part: 3-3a - Upper Thracian Morphostructural Zone: 3- continental part, 3a- margin part: 4 - 4a - Sakar-Strandzha Morphostructural Zone Morphostructural Zone: 4- continental part, 4a- margin part: 5- Lower Thracian Morphostructural Zone; 6-11 - subaqual margin area: 6-8 - continental shelf: 6- high step, 7- down step, 8- fault zone; 9- continental slope, 10- continental foot, 11- Black Sea Bottom; 12 - west border of the West Black Sea Passive Continental margin, 13- some important faults, 14- border between the morphostructural zones, 15 - boundary between Turkey and Bulgaria 


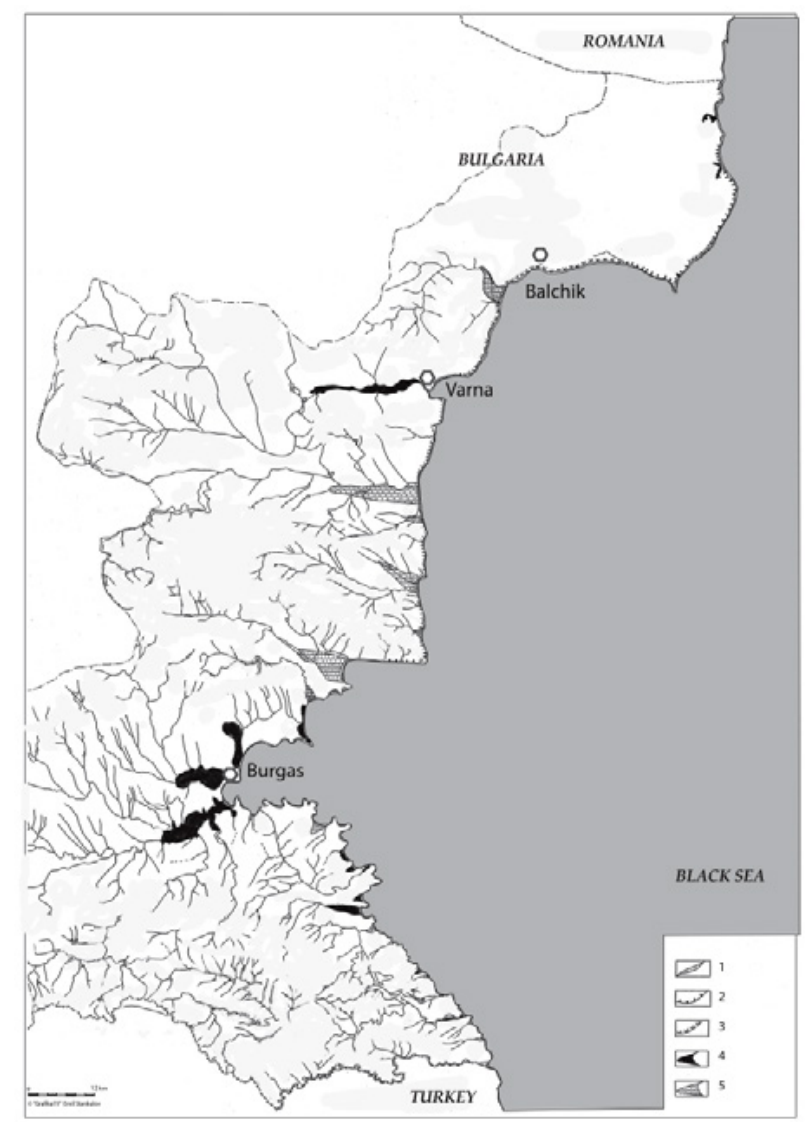

Figure 11: Survey sketch map of the firths and lacks along the Bulgarian Black Sea Coast 1- lack, 2- firth

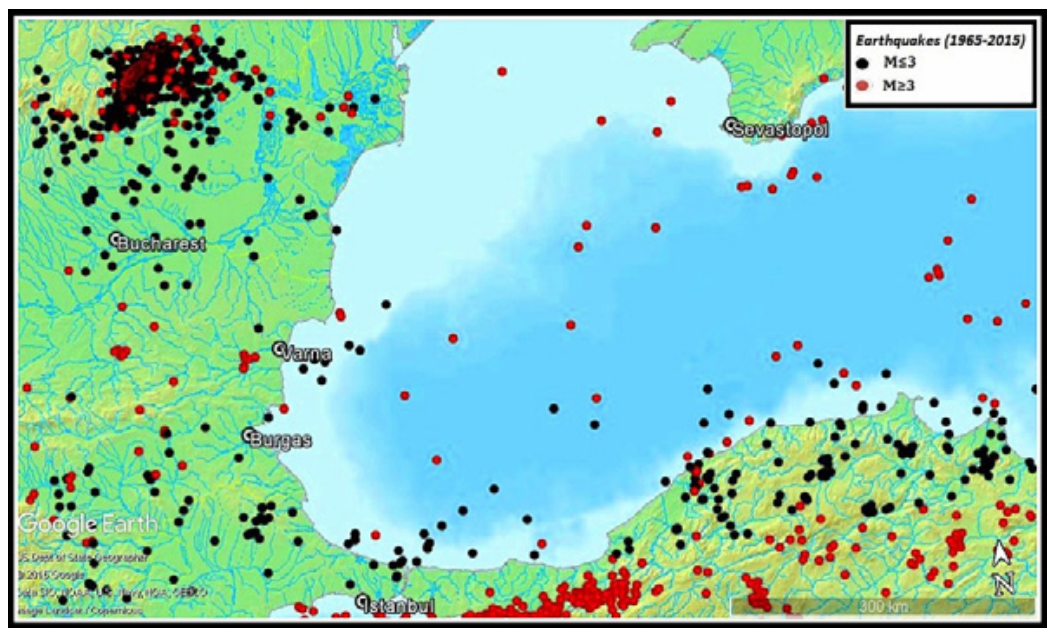

Figure 12: Comparative map of the seismic activity between the West Black Sea Passive Continental Margin Area and the neighbor areas during the period of $1965-2016$

(after USGS Seismic hazard program - online available from https://earthquake.usgs.gov/earthquakes/search) 


\section{CONCLUSION}

The Black Sea Neozoic Passive Continental Margin marks the natural „bridge” between the Moesian and Bulgarian continental microplates and the Black Sea oceanic microplate. It was coming in to being after the saturation between the terrains which are composed the Neo Europe Continental Massif South East Part during the Early Paleogene.

The subaerial part of the margin includes the most east parts of the South Moesian, Hemus, Upper Thracian and Sakar-Strandzha Morphostructural Zones (Fig. 10). The subaquatic margin part is composed by the consequently orderly step lower to the Black Sea Bottom: high shelf zone, lover shelf zone, continental slope and continental foot.

The Black Sea Neozoic Passive Continental Margin is characterized by low seismic activity (Fig. 12). It is concentrated in some fault zones.

Acknowledgement: Project № РД-08-121/04.02.2019 “Resource potential as an opportunity for cross-border cooperation”, Konstantin Preslavsky University of Shumen.

Grant Support: This work is supported by the Bulgarian Ministry of Education and Science under the National Program for Research "Young Scientists and Postdoctoral Students".

Conflict of Interest: The authors' participation is equivalent

\section{REFERENCES}

Tzankov, Tz., N. Spasov, K. Stoyanov. (2005). Neogene-Quaternary paleogeography and geodynamic of Middle Struma (South-West Bulgaria). SWU „Neofit Rilski”, Blagoevgrad, 199.

Tzankov, Tz. (2009). About the contemporary geodynamics of the Balkan peninsula. In: Global changes, vulnerability, mitigation and adaption. Fifth International conference, 17-18 April 2008, Sofia University „St. Kliment Ohridski”. Proceedings, Sofia, Bulgaria, 126-128.

Tzankov, T., Sv. Stankova. (2011). Principal tendencies of the Quaternary morphogenesis in the Eastern Part of Balkan Peninsula. Fourth International Scientific Conference (FMNS2011) - SWU „Neofit Rilski”, Blagoevgrad. Volume 2, 266-273.

Tzankov, Tz., S. Stankova. (2012). Principles and criteria of the regional morphostructural dividing of the eastern part of Balkan Peninsula. Annual of Konstantin Preslavsky University of Shumen, 22-25.

Tzankov, Tz., Sv. Stankova. (2014). Borders and principal regional units of the Bulgarian Continental Micro Morphotecture (East Part of Balkan Peninsula). Acta Scientifica Naturalis, Shumen, volume 1, 218-232.

Tzankov, Tz., S. Stankova. (2015). About the origin and morphostructure of the Black Sea Basin. Prosedings of the XIII Conference "Natural Sciences'2015”, September 25-27, 2015,Varna, Bulgaria, 74-76.

Tzankov, Tz., Sv. Stankova. (2016). About the origin and morphostructure of the Black Sea Basin. Proceedings of the XIII Conference "Natural Sciences 2015", Shumen, 74-76.

Tzankov, Tz., Sv. Stankova, R. Iliev. (2017). Morphostructure of the Sakar and Strandzha Mountains, Acta Scientifica Naturalis. Volume 4, Issue 1, Pages 89-93. DOI: https://doi.org/10.1515/asn-2017-0014.

Tzankov, Tz., S. Stankova, R. Iliev, I. Mitkov. (2018). Late Quaternary morphostructural generations in the eastern part of Balkan Peninsula. SocioBrains. Issue 41, Januari 2018, 188-197.

USGS Seismic hazard program, Online available from https://earthquake.usgs.gov/earthquakes/search/ (01.06.2019). 